DOI: https://doi.org/10.32839/2304-5809/2021-7-95-5

УДК 378.046.4.

Мельниченко О.В., Бурда Ю.С. Київський університет імені Бориса Грінченка

\title{
АНДРАГОГІЧНІ ЗАСАДИ НАВЧАННЯ ДОРОСЛИХ
}

Анотація. У статті розглянуто засади становлення та розвитку освіти дорослих як джерела подальшого формування і вивчення освіти дорослих у XXI столітті; обгрунтовано андрагогічні засади навчання дорослих. Автори приділяють значну увагу сутності андрагогіки як науки про закономірності та особливості освітнього процесу навчання дорослих. У статті досліджуеться специфіка андрагогічних процесів, світовій досвід в освіті дорослих. Розкрито теоретико-методологічні проблеми андрагогіки. Автори аналізують значення розвитку андрагогіки як науки, що дозволяе формулювати і реалізовувати основні цілі освіти дорослих в контексті життевого шляху людини. Визначено складові освітньої ланки навчання дорослих людей. Розглянуто наявну законодавчу базу для розвитку освіти дорослих та розробку законопроекту «Про освіту дорослих». Проаналізовано вплив безперервної освіти на національному та регіональному рівнях. Ключові слова: андрагогіка, андрагогічні принципи, освіта дорослих, якість освіти, неперервна освіта.

Melnichenko Olga, Burda Yuliia Borys Grinchenko Kyiv University

\section{ANDRAGOGICAL PRINCIPLES OF ADULT TEACHING}

Summary. The article considers the principles of formation and development of adult education as a source of further formation and study of adult education in the XXI century. The views of M. S. Knowles are considered as a basis, on the basis of which modern principles of andragogy are distinguished. The necessity of using the andragogical approach in the educational program of adult education is substantiated. The authors determine that the growing contradictions in the education system of Ukraine has necessitated the transition to a qualitatively new model of providing educational services, which is based on modern worldviews. The situation requires a paradigm shift to support the formation and development of teachers and educational programs in higher education institutions along the entire trajectory of their activities. The authors pay considerable attention to the essence of andragogy as a science of patterns and features of the educational process of adult learning. This article explores the specifics of andragogical processes, the world experience of adult education, compares the existing adult educational policy in the world and its implementation in Ukraine. Particular attention is paid to the consideration of the law on education, the concept of the New Ukrainian School and the bill "On Adult Education", which currently remains unapproved. The authors analyze the importance of the development of andragogy as a science that allows to formulate and implement the main goals of adult education in the context of human life. The five main components of adult education are identified. Training, retraining, advanced training of workers and unemployed people are defined as areas of formation of the adult education system; educational institutions and training centers that provide services for teaching and mastering certain skills for adults were identified and the lack of specialized government programs was pointed out. It is noted that adult education today is based on continuing education, self-education and self-development. The article emphasizes the importance of training future teachers for adult education, the importance of a logically constructed program and principles that aim for practice-oriented learning and are an integral part of the quality of education. The impact of continuing education at the national and regional levels is analyzed; the European experience and the Upskilling Pathways program are considered, in particular, as a reference point for the further development of adult education in Ukraine.

Keywords: andragogy, andragogical principles, adult education, quality of education, continuing education.

Постановка проблеми. У сучасному індрор1 маційному суспільстві діють певні чинники, що обумовлюють необхідність постійного оновлення людиною отриманої освіти та усіх знань взагалі.

По-перше, це - розвиток нових технологій, які є, з одного боку, каталізатором, що забезпечує стрімке зростання міжособових і міжгрупових зв'язків, а 3 іншого - вони змінюють напрямки, тим самим, трансформуючи соціальну структуру суспільста.

По-друге, це - стан демографрічної ситуації в світі, яка примушуе людину змінювати професію, або проходити додаткове навчання.

По-трете, це - посилення світових міграційних процесів, що сприяють активному обміну думками, теоріями, знаннями та досвідом.

Саме ці чинники й викликали до життя побудову системи неперервної профресійної освіти, що охоплюе все активне життя людини. При џьому різноманіття і неперервність розглядається не тільки як перспективна тенденція, але і як умова досягнення нової якості освіти. Зміни в сис- темі освіти вимагають навиків неперервного навчання, пізнавальної діяльності, колективних форм взаємодії і передачі знань.

Поширення у світі та Свропі зокрема, так званої «освіти протягом життя» призвело до того, що вона стала сучасним трендом та вимогою сьогодення. В Україні неперервна освіта теж є не менш актуальною, що знайшло своє відображення у законі «Про освіту» [3], який створив певні умови для розвитку освіти дорослих протягом життя. На сьогодні можна констатувати орієнтир нормативно-правової бази України до створення умов розвитку багаторівневої програми неперервної освіти. В Україні, як і у Свропейському освітньому просторі, однією з поміж дев'яти головних компетентностей визначено «освіту протягом життя», що вважається головним принципом навчального процесу сьогодення [4].

Отже, дослідження теоретичних і практичних засад андрагогіки та їх застосування в українському освітньому середовищі є досить актуальними і потребують уваги українських науковців. 
Ефективність та доречність дослідження концептуальних ідей освіти дорослих підтверджено і першочерговими напрямами наукових досліджень НАПН України на 2021-2025pp. Серед них можна визначити такі як: «Методологічні, теоретичні, методичні засади розвитку освіти різноманітних категорій дорослих в умовах глобалізації та інтеграції в країні» та «Тенденщії розвитку європейської ланки профресійної освіти і підготовки, вищої освіти та дослідницького простору» [5].

Аналіз останніх досліджень і публікацій. Питанням дослідження закономірностей та особливостей андрагогіки, а також їі ролі в освіті дорослої ланки населення займались багато зарубіжних науковців, зокрема: Х. Гансельманн, П. Джарвіс, Е. Ліндеман, О. Капп, С. Хоф, М.Ш. Ноулз, Ф. Пеггелер, Є. Росенсток, Е.Л. Трондайк, С. Хофр та інші. На сьогоднішній день андрагогічні принципи і підходи лягли в основу прац сучасних вітчизняних вчених-андрагогів: О. Аніщенко, С. Архіпової, Л. Даниленко, О. Дубасенюк, Л. Лук'янової, Н. Ничкало, О. Огієнко, В. Олійник, С.О. Сисоєвої та інших. Однак, окремі моменти використання андрагогічних засад у освітньому процесі залишаються недостатньо висвітленим і потребують подальшого дослідження і розвитку.

Виділення не вирішених раніше частин загальної проблеми. Дослідження специфіки андрагогічних процесів в контексті сучасної вищої освіти, аналіз світового досвіду та його вплив на освітні процеси у ЗВО України.

Мета статті. Метою статті є дослідження андрагогічних принципів освіти дорослих та їх впливу на підвищення якості неперервної освіти в сучасних умовах, а також визначення практичних андрагогічних знань та умінь для ефективної роботи 3 дорослими щодо сприяння їх особистісному і профресійному розвитку й самовдосконаленню.

Виклад основного матеріалу. Як зазначає «Енциклопедія освіти», перші спроби виділити андрагогіку із загальної педагогіки та, власне, поява самого терміну у XIX ст. належать німецькому історику освіти К. Каппу, який у 1833 р. запропонував виокремлювати цю галузь знань, вказавши це у книзі про педагогічні погляди Платона [6]. Але лише з часом прийшло сучасне розуміння цього терміну. Андрагогіка розглядає освіту в контексті життевого шляху людини. Iї предмет - це соціальна освіта, тобто багатоаспектна неперервна освіта дорослих, яка здійснюеться в інститутах формальної, неформальної і інформальної освіти відповідно до соціокультурних умов. Так, у широкому сенсі, андрагогіку трактують як поняття та науку, що допомагає особистісній реалізації людини упродовж всього життевого циклу. Як відомо, більшість людей починає реалізовуватись у досить молодому віці, проте не менш значна кількість все ж таки знаходить покликання протягом усього життя. Андрагогіка сприяе такому розвитку особистості, надає допомогу у пошуках свого місця в житті, реалізовує віднайдені приховані можливості людини. До того ж, сучасний світ вимагає постійного розвитку, що зумовлений технологізацією, появою нових професій тощо.

У 1970 році американський педагог М.Ш. Ноулз розробив та відкрив світові суб'єктивні положення андрагогіки, зокрема:
- дорослій людині, що навчається, необхідна провідна роль у процесі навчання;

- вона, будучи повністю сфрормованою особистістю, встановлює конкретні цілі навчання, є самостійною та самореалізованою;

- доросла людина володіє профресійним і життевим досвідом, знаннями, вміннями, навичками, які повинна використовувати у процесі навчання;

- дорослий шукає найбільш швидке застосування отриманим знанням та вмінням під час навчання;

- процес навчання обмежуеться, або, навпаки, сприяе навчанню соціологічними, матеріальними, фрізичними, психологічними фракторами;

- навчання проходить у фрорматі організованої спільної діяльності всіх, хто навчається [7].

Однією з головних засад андрагогіки можна визначити першочергову роль у процесі навчання не того, хто навчає, а того, хто навчається. У зв'язку з цим, навчання на засадах андрагогіки вимагає нових форм та методів освітнього процесу. Замість лекційних занять концепція андрагогіки ставить акцент на практичне відпрацювання матеріалу, проведення дискусій, ділових ігор, кейсів та вирішення конкретних завдань і проблем [11].

Головні положення андрагогіки М. Ноулза були доповнені сучасною наукою, яка виділяе наступні засади андрагогіки:

1. Пріоритетність самостійного навчання.

2. Згрупована діяльність людей, що навчаються.

3. Використання життевого досвіду.

4. Коригування застарілого досвіду, що обмежуе засвоєння нового матеріалу.

5. Індивідуальний підхід до навчання.

6. Редрлективність.

7. Необхідність практичних результатів.

8. Системне навчання.

9. Актуальність результатів навчання.

10. Принцип розвитку тих, хто навчаеться [8].

Кожна 3 цих засад повинна містити у собі ціль, підходи, методи навчання, визначити взаємодію усіх суб'єктів навчального процесу.

На сьогодні, в Україні $є$ п'ять основних складових освітньої ланки навчання дорослих людей:

- післядипломна освіта;

- професійне навчання працівників;

- кваліфрікаційні рівні підвищення;

- безперервна самостійна освіта;

- складові, що прописані у законодавстві та запропоновані суб'єктом освітньої діяльності.

3 цього переліку можна зробити висновок про те, що держава відноситься з розумінням до освіти дорослих, як складової навчання впродовж усього життя. Законодавство сприяє реалізації та покращенню прав кожної повнолітньої особи з урахуванням особистих потреб людини та підвищенню економпічної складової держави [1]. Однак, слід зазначити, що нині в Україні відсутня планова політика відповідного впровадження освіти і навчання дорослих, окрім самостійного розвитку та підвищення кваліфрікацій на підприемствах. Аналіз напрацювання у щій сорері свідчить про те, що на сьогодні можна говорити лише про регулювання деяких елементів системи освіти та навчання дорослих.

Наступним кроком у формуванні системи освіти для дорослих є підготовка, перепідготовка, підвищення кваліфікаційного рівня робітників та безробітних людей, враховуючи зміни на ринку пращі. Проте така структура має обмежене коло адресатів. 
Окрему частину в самому процесі навчання займає коло приватних, спеціалізованих установ та тренінгових центрів, котрі надають послуги щодо навчання й оволодіння певними навиками усім бажаючим на комерційній основі [9].

Як приклад розвитку цього напряму, можна навести колаборацію МОН України з Німецькою асоціацією народних університетів. В i межах розпочалась комплексна робота щодо розробки законопроекту «Про освіту дорослих», який в середині 2020 року вже виносився для громадського обговорення [10]. До розгляду було представлено основні положення, серед яких:

- визначені основні напрямки освіти дорослих;

- визначено завдання та принципи освіти дорослих;

- визначені основні засади державно-приватного партнерства та міжнародної діяльності у цій сорері;

- відведено окреме місце терміну «провайдер освіти дорослих».

Свропейський Союз (ЄС) майже на 10 років раніше від України підняв питання, щодо освіти дорослого населення, а у 2016 році за програмою «Upskilling Pathways» почав реалізовувати допомогу дорослим, що не мають середньої або профресійної освіти. Основним завданням ціеї програми стало отримання мінімальних рівнів грамотності серед дорослого населення задля подальшого підвищення рівня навчання та освіти.

Для розвитку освіти дорослих в Україні актуальним є включення в суспільне життя соці- ально незахищених груп дорослого населення: безробітних, людей пенсійного віку, військовослужбовців, людей 3 обмеженими фізичними можливостями, мігрантів, засуджених дорослих, позбавлених волі тощо.

Висновки. Андрагогіка розкриває принципи, засоби і методи, за допомогою яких підвищуеться фрункція соціалізації (i соціальної реабілітації) освітнього процесу. Актуальності андрагогіка набувае у зв'язку з необхідністю вивчення освітніх потреб різних категорій і груп населення України, моделюванням фрорм та фрункцій навчання дорослих а також із законодавчим, змістовним та технологічним його забезпеченням. Крім того, розвиток освіти дорослих сприяе активній участі громадян у демократичних процесах на загальнодержавному та регіональному рівнях, а також вплине на рівень розвитку дієвого громадянського суспільства. Розвиток неперервної освіти дорослих в Україні сприятиме:

- на національному рівні - форомуванню та реалізації політики зайнятості населення;

- на регіональному рівні - реалізації сервісно-орієнтованої політики у сфері зайнятості незахищених категорій населення.

Перспективою подальших досліджень андрагогічних принципів навчання дорослих $€$ вивчення гендерного аспекту під час працевлаштування дорослих в Україні та важливості забезпечення рівності можливостей чоловіків і жінок в доступі до усіх фрорм навчання дорослих.

\section{Список літератури:}

1. Боярська-Хоменко А.В. Розвиток питань освіти у педагогічній думці. URL: www.ps.journal.kspu.edu

2. Гриневич Л. Концептуальні засади формування середньої школи. URL: https://mon.gov.ua/

3. Закон України «Про освіту». URL: https://zakon.rada.gov.ua/laws/show/2145-19\#Text

4. Ключові новації в освіті. URL: https://mon.gov.ua/storage/app/media/zagalna\%20serednya/BOOKLETTE_ INFO-ZAKON-2018_PRESS.pdf

5. Концептуальні засади розвитку освіти дорослих. URL: https://cutt.ly/NmXAiAx

6. Кремень В.Г. Енциклопедія освіти. Київ : Юрінком Інтер, 2008. 1040 с.

7. Лазоренко О., Колишко Р. Навчання дорослих в Україні. URL: https://www.civic-synergy.org.ua/

8. Ноулз М.Ш. Андрагогіка: принципи практичного навчання для дорослих. URL: http://www.elitarium.ru/

9. Орлова О.А. Андрагогічні засади оновлення підготовки вчителів у системі післядипломної освіти. Теорія і практика підготовки майбутніх учителів до педагогічної дії. URL: http://eprints.zu.edu.ua/

10. Проект Закону України «Про освіту дорослих». URL: https://mon.gov.ua/ua/news/mon-proponuye-dlyagromadskogo-obgovorennya-proyekt-zakonu-ukrayini-pro-osvitu-doroslih

11. Turos L. Andragogika. Zaris teorii oswiaty i wychowania doroslych. Wyd. 2. Warshawa : PWN, $1978.121 \mathrm{~s}$.

\section{References:}

1. Boyars'ka-Khomenko A.V. (2019) Rozvitok pitan osviti u pedagogichnii dumtsi [Development of education issues in pedagogical thought]. Available at: www.ps.journal.kspu.edu

2. Grinevich L. (2016) Kontseptualni zasadi formuvannya serednoi shkoly [Conceptual principles of secondary school formation]. Available at: https://mon.gov.ua/

3. Zakon Ukraïni "Pro osvitu" [Law of Ukraine "On Education"]. Available at:https://zakon.rada.gov.ua/laws/ show/2145-19\#Text

4. Klyuchovi novatsii v osviti [Key innovations in education]. Available at: https://mon.gov.ua/storage/app/media/ zagalna\%20serednya/BOOKLETTE_INFO-ZAKON-2018_PRESS.pdf

5. Kontseptualni zasadi rozvitku osviti doroslikh [Conceptual principles of adult education development]. Available at: https://cutt.ly/NmXAiAx

6. Kremen' V.G. (2008) Entsiklopediya osvity [Encyclopedia of Education]. Kyiv: Yurinkom Inter, 1040 p.

7. Lazorenko O., Kolishko R. (2018) Navchannya doroslikh v Ukraini [Adult education in Ukraine]. Available at: https://www.civic-synergy.org.ual

8. Noulz M.Sh. (2016) Andragogika: printsipi praktichnogo navchannya dlya doroslikh [Andragogy: principles of practical training for adults]. Available at: http://www.elitarium.ru/

9. Orlova O.A. (2011) Andragogichni zasadi onovlennya pidgotovki vchiteliv u sistemi pislyadiplomnoï osviti [Andragogical principles of updating teacher training in the system of postgraduate education]. Teoriya $i$ praktika pidgotovki maibutnikh uchiteliv do pedagogichnoi dii. Available at: http://eprints.zu.edu.ua/

10. Proekt Zakony Ukrainy "Pro osvitu doroslikh» [Draft Law of Ukraine "On Adult Education"]. Available at: https://mon.gov.ua/ua/news/mon-proponuye-dlya-gromadskogo-obgovorennya-proyekt-zakonu-ukrayini-pro-osvitu-doroslih

11. Turos L. (1978) Andragogika. Zaris teorii oswiaty i wychowania doroslych. Wyd. 2. Warshawa: PWN, $121 \mathrm{~s}$. 